\title{
PREDICTIVE ABILITY OF CHOSEN BANKRUPTCY MODELS: A CASE STUDY OF SLOVAK REPUBLIC
}

\author{
Anna Siekelova ${ }^{1}$, Tomas Kliestik ${ }^{2}$, Peter Adamko ${ }^{3}$ \\ ${ }^{1,2,3}$ University of Zilina, Faculty of Operation and Economics of Transport and Communications, \\ Department of Economics, Univerzitna 1, 01026 Zilina, Slovak Republic \\ Ianna.siekelova@fpedas.uniza.sk \\ ${ }^{2}$ tomas.kliestik@fpedas.uniza.sk \\ 33peter.adamko@fpedas.uniza.sk
}

\begin{abstract}
Bankruptcy models are used to assess credit risk and predict financial situation to indicate the probable bankruptcy of the company. Contribution deals with the application of chosen bankruptcy models in analysing and predicting the financial health of selected companies. Most of the models have been developed abroad. In case of Slovak Republic, its application and correctness of the results can be problematic; therefore, we have focused primarily on those that have emerged in countries with a similar economy. We have calculated the selected prediction models in a sample of 500 Slovak enterprises. Predictive ability lower than $64 \%$ is considered as unfavourable. As part of the contribution, based on expert literature and relevant legislation, we have defined the criteria that allow to divide businesses into two groups: prosperous and non-prosperous. In the end, we compared the results of the selected models with the inclusion of enterprises in a prosperous and nonprosperous group based on the criteria set by us. We also dealt with examining of error types I (when an enterprise in bad financial condition is included in a non-bankruptcy group) and II (when an enterprise in good financial condition is included in a bankruptcy group). The aim is to analyse the predictive ability of the selected bankruptcy models.
\end{abstract}

Keywords: Bankruptcy; bankruptcy model; prediction of financial health; predictive ability; Slovak Republic

JEL Classification: C53, G33.

\section{Introduction}

Predicting bankruptcy is becoming increasingly important for corporate governance. Many different bankruptcy models are used to predict the upcoming financial difficulties. A large number of economists around the globe are dealing with the development of predictive bankruptcy models that could give a timely prediction of incoming or emerging financial hardship. In this way, they can offer advice to users on how to prevent the bankruptcy of their company or how to delay the bankruptcy as much as possible. Neither model has one hundred percent speech ability. Each mechanism has its strengths and its weaknesses. Therefore, the choice between them is not easy. The aim is to analyse the predictive ability of selected bankruptcy models. Most of the older verified prediction models come from abroad, especially from the US. However, the US economic environment is completely different from that of the emerging markets. Therefore, the relevance of using these models may be questioned. However, new predictive models are being developed and tested under the condition of emerging markets. As part of our contribution, we mainly focused on them and we analysed their predictive abilities through a matrix of change. In this contribution, we were working with a database consisting of 500 financial statements of Slovak enterprises that capture the years 2016 and 2017. At the outset, we have divided the enterprises into threatened with bankruptcies and those to whom bankruptcy is not threatened, based on the criteria that are more specifically mentioned in the methodological part of the contribution. We subsequently evaluated the financial health of these businesses through four selected prediction models. In the last part we compared the results. We recorded the results of the 
comparison in the matrix of changes. We have examined how many times a match is made between placing a business in a bankruptcy or non-bankruptcy group on the basis of the criteria chosen by us (according to The Commercial Code) and between assessing the financial stability set by the selected models. On the basis of which, it was possible to determine the predictive ability of the model under conditions of the Slovak Republic. The relevance of the results is determined by a relatively large sample of enterprises.

We have found different definitions of bankruptcy models in book publications. According to Svabova L. and Kral P., bankruptcy models are a system of several ratios that are weighted, and their weighted sum gives a score that determines whether an enterprise is prone to financial distress and bankruptcy, or a bankruptcy is very unlikely, or the score is in the grey zone, that is, inside an interval, when the bankruptcy probability cannot be decided (Svabova, Kral 2016). According to S. Cisko and T. Kliestik, the role of bankruptcy models is to inform the user in advance of whether the business is in the near future threatened with bankruptcy (Cisko, Kliestik 2013). Bankruptcy models predict business failure and are built on empirical data from the economy and the market (Virag, Kristof 2005). It is important to remember that the success of a given model depends, in particular, on the input data. There is a possibility that this information may be somewhat distorted. Point assessment methods, mathematical-statistical methods and neural networks are used to forecast the future development of a business entity's financial position. Numerous authors have used mathematical and statistical methods on which they have constructed their models, and these are still well-proven. Bankruptcy models based on mathematical and statistical methods are based on discriminatory analysis (one-dimensional, multidimensional), logistic regression (LOGIT, PROBIT models), and structural models form a specific group. Over time, a number of economists are beginning to take on more advanced methods of modelling, mainly neural networks, as well as genetic algorithms, decision trees, proportional hazard models, expert systems or mathematical programming.

\section{Literature Review}

One of the oldest papers dealing with business failure and bankruptcy prediction was an article by Paul J. FitzPatrick (1932) titled 'A Comparison of the Ratios of Successful Industrial Enterprises Those of Failed Companies' in the 1930s. The beginnings of the prediction models are mainly related to the United States. William H. Beaver's pioneer work (1966) titled 'Financial Ratios and Predictors of Failure', and in particular Edward I. Altman's (1968) 'Financial Ratios. Discriminant Analysis and Prediction of Corporate Bankruptcy', developed the first business insolvency models. One-off and multi-purpose approaches and available data from the US companies were used. We find very interesting the fact that the emergence of predictive models was not the result of any economic crisis or other external factors that would have a significant impact on the functioning of the country's economy but the natural development of financial management research (Mousavi et al. 2015).

Looking at the method of one-dimensional discriminatory analysis, which was used among the first by W. H. Beaver in his work, does not use any complicated apparatus apart from the graphical representation of the values of the selected ratios. His approach is based on the so-called dichotomous classification test, where multiple ratios with highest predictive power are selected. However, over time, many opinions have emerged that have negated the unambiguous predictability of financial health by Beaver. As a result, more complex, so-called multidimensional statistical methods were created. These make it possible to categorize businesses definitely. One of the authors of multidimensional methods, namely the multidimensional discriminatory analysis, was in fact E. I. Altman. His work is based on the ideas of R. A. Fisher (1936), specifically his article 'The Use of Multiple Measurements in Taxonomic Problems'. By using this analysis, businesses can be divided into two groups - bankruptcy and non-bankruptcy businesses based on a linear combination of characteristics that best differentiates between these two groups. In his research, he used 5 financial ratios that have the best ability to predict the financial health of the enterprise. He assigned them weight and created a discriminatory function. However, along with the methodology, he also studied its reliability, and respectively error. He divided the faulty ratings into two types: Error $\alpha-$ Faulty Type I, in which non-prosperous businesses are ranked among prosperous and Error $\beta$ - Faulty Type II, where prosperous businesses are ranked among non-prosperous. E. I. Altman, therefore, could be 
identified as the father of predictive models, because after his studies and research, further development occurred, not only in the United States but also globally. Another national business environment or different types of accounting systems led Professor E. I. Altman to develop specification of his models by applying them to other national economies such as Altman, Kim and Eom (1995), Altman, Lavalle (1981) or Altaman et al. (1972). He also attempted to design models for the rapidly expanding markets Altman, Hotchkiss (2006). In addition to Altman, many other pioneers in the field of predictive models wanted to apply their models to other national economies such as Taffler (1982), Koban (1978), Horrigan (1996) Kralicek (1990) (Weissova, Gregova 2016; Abiodun et al. 2017).

In his publication, T. E. McKee (2000) presented a division of several methods of constructing prediction models: one-dimensional models, multiple discriminatory analysis, linear probability models, LOGIT and PROBIT models, decision trees, proportional hazard model, expert systems, mathematical programming, neural networks, or a rough set approach. We can say, that the apparatus of discriminatory analysis is thus overcome by modern methods, one of which is logistic regression. This method is based on finding a dependency of the logistic variable $(0-$ non-bankruptcy enterprise and 1 - bankruptcy enterprise) from multiple independent variables, which means from financial ratios. Modified regression analyses are called LOGIT and PROBIT models. The beginnings of the LOGIT model are associated with J. Ohlson (1980) and J. E. Fernandes (2005) and PROBIT analysis with Mark E. Zmijewski (1984) (Jones 1987; Altman 2005).

Within the Slovak Republic, models were developed for one area of the national economy, namely agriculture. These are the CH-index of Z. Chrastinova (1998) and the G-index of L. Gurcik (2002). The CH-index of Z. Chrastininova (1998) is created by a discriminatory function and is among the first bankruptcy models of ex ante analysis of agricultural enterprises. It was published in the publication titled 'Methods of Valuation of Economic Creditworthiness and Financial Situation Prediction in Agricultural Enterprises'. Testing was done on a sample of 1123 enterprises. The result of this test is the claim that the model can be realistically applied in SR conditions. The model classifies most of the enterprises into the gray zone as a troubled enterprise, which mainly results in long maturities of the liabilities. This model is used not only in Slovakia but also in the Czech Republic. (Chrastinova 1998) G-Index of L. Gurcik (2002) is a multiple discriminatory analysis model. He published it under the title 'G-index - Method of Predicting the Financial Condition of Agricultural Enterprises'. He focused on a set of 60 agricultural enterprises, which he divided into prosperous and non-prosperous according to their profitability and return on equity (Gurcik 2002). However, the index or part of it cannot be used to predict a problem of insolvency (Fanelli, Ryden 2018). Another one, within the Slovak Republic, is the model predicting the future decline of businesses operating in the conditions of the Slovak Republic. The author of the model is M. Gulka (2016), who developed it through logistic regression. All business entities based in the SR were the object of the survey, with the exception of the financial sector. Altogether, the testing database contained 120,854 enterprises. The study has brought interesting results. Using only the financial ratios, the accuracy of the model was $75 \%$ to $80 \%$. The surveyed set of business subjects was also applied to Altman's Z-score. Subsequently, the Gulka's model and Z-score were compared. The result is a higher success rate of $75.64 \%$ compared to the Z-score with $55.09 \%$. M. Gulka in his thesis also questions the usability of the Altman Z-score model in SR conditions, as Z-score denotes many Slovak companies as failing. This is mainly due to the fact that Z-Score was developed for the US companies and in different times (Gulka 2016; Cisko, Klieštik 2013). M. Gulka was awarded the NBS Governor Prize for his research in his diploma thesis titled 'Model of Bankruptcy Prediction of Businesses Operating in the Slovak Republic'. Other author J. Hurtosova (2009) also developed a model using logistic regression in her dissertation thesis titled 'Construction of a rating model, a tool for assessing the creditworthiness of an enterprise'. The input data for the model came from an anonymous commercial bank based in the Slovak Republic, which provided information on business entities (legal entities and individuals). The author examined a sample of 427 business entities and utilized four of the original 126 financial ratios. 
In the current literature, we find a wide range of available bankruptcy models, which vary considerably by their applicability in the conditions of the Slovak Republic, depending on the level of their ability to report (Weissova, Durica 2016; Neumaierova, Neumaier 2005; Rowland et al. 2016 ).

\section{Methodology}

Bankruptcy models are aggregated indexes, the main purpose of which is to express the financial and economic situation of a company using a single number. They are based on the construction of classification models using historical data. They are directly based on the assumption that past values of suitably selected financial and economic indicators can indicate the development of financial health. Bankruptcy models therefore deal with a possible default of the business, in other words, warn against the likely bankruptcy of a business. In bankruptcy models, their predictive ability is verified. Some of them should be used within a precisely specified industry (Hurtosova model, Gurcik model), others take into account certain specificities of the country in which they were created. Especially when applying foreign models in the conditions of the Slovak Republic, a problem of their low predictive ability occurs. Predictive ability of less than $64 \%$ is considered to be unfavourable, on the contrary, more than $70 \%$ is considered to be good, higher than $83 \%$ is relatively high, and in cases where predictive ability reaches $97 \%$, we can talk about extreme. The paper also focuses on examining the extent of classification errors. For a Type I error, the bankruptcy is classified as a prosperous. Type II error on the other hand, classifies a prosperous enterprise as bankrupt one (Zavgren 1985). As part of our paper, we have focused on the calculation of selected prediction models, which are very often used in our territories to predict bankruptcy, and then we compare the results of these models with whether or not the enterprise is actually in decline or whether it is threatened or not by bankruptcy. For comparison, however, it was first necessary to characterize the criteria that distinguish a prosperous and non-prosperous enterprise. In defining the following criteria, we mainly took into account the legislative adjustment of the subject matter. The declaration of bankruptcy of the debtor's assets is considered when he goes bankrupt. The bankruptcy is governed by $\S 3$ of Act no. 7/2005 Coll. on Bankruptcy and Restructuring, as amended, according to which the debtor is in decline if he is insolvent or overdebted. It is therefore necessary to define clear rules when an enterprise is in decline or being overdebted and, on the basis of these rules, to divide businesses from our group into prosperous and non-prosperous.

- A legal person is insolvent if it is unable to pay at least two monetary obligations to more than one creditor for 30 days after the due date. With such a large sample of businesses that we will be working with, it will not be possible to determine individually how many financial obligations every single company has over maturity (and how long) or the exact number of their creditors. This cannot be ascertained directly from the financial statements. Therefore, we would suggest using an overall liquidity indicator. The decisive criterion for nonprosperous businesses is as follows:

$$
L_{3}<1
$$

Another criterion may be achievement of profit. The inability of a business to generate profits may lead to insolvency. The decisive criterion for non-prosperous businesses is as follows:

$$
\text { Earning after tax } \leq 0
$$

- An overdebted company is required to keep accounts under a special regulation, has more than one creditor and the value of his obligations exceeds the value of his assets. Therefore this company has a negative equity. The decisive for non-prosperous businesses is as follows:

$$
\text { assets }-(\text { liabilities + liabilities accruals })<0
$$


Amendment to Act no. 513/1991 Coll. The Commercial Code, as amended, comes with a new institute - a company in crisis, that came into force on 01.01.2016, which we can also consider when assessing the client's creditworthiness. The company is in a crisis when it is in decline or at a risk of decline. Decline has already been defined above. Amendment to Act no. 513/1991 Coll. The Commercial Code, as amended, comes with the definition of the conditions under which companies are at a risk of decline. Companies are at risk of decline if their equity and liabilities ratio is less than 8 to 100 . Under the transitional regulation, the ratio of 8 to 100 will only be used after 2018 . Until then, the rules will be even less strict. In 2016, the ratio of equity and liabilities will be 4 to 100 and in 2017 ratio 6 to 100. We suggest using a ratio of 6 to 100 and from the next year to use the recommended ratio of 8 to 100 for verification. The decisive criterion for non-prosperous enterprises is as follows:

$$
\frac{\text { equity }}{\text { liabilities }+ \text { liabilities accruals }}<0.06 \text { (or } 0.08 \text { from year 2018) }
$$

According to the selected criteria, we propose to designate these companies as non-prosperous:

[1] All of which apply: (regardless of condition [2])

$$
\text { assets }-(\text { liabilities + liabilities accruals })<0
$$

[2] Those for which the inequality of the first condition does not apply, but all three following conditions apply at the same time:

$$
\begin{gathered}
L_{3}<1 \\
\text { Earning after tax } \leq 0 \\
\frac{\text { equity }}{\text { liabilities }+ \text { liabilities accruals }}<0.06 \text { (or } 0.08 \text { from year 2018) }
\end{gathered}
$$

In the second part of the practical, we focused on the calculation of the selected models used for predicting bankruptcy. We focused primarily on the most used Czech and Slovak prediction models, because they should take the specifics of the Slovak economy into utmost account and should therefore have the highest predictive ability. An overview of the calculation of the used financial health prediction models is shown in Table 1.

Table 1. An overview of the calculation of the used financial health prediction models (Source: author's compilation)

\begin{tabular}{|c|c|}
\hline $\begin{array}{c}\text { Jakubik Teply } \\
\text { model }\end{array}$ & $p=\frac{e^{2,4192+2,5779 x_{1}+1,7863 x_{2}-3,4902 x_{3}-2,4172 x_{4}+1,7679 x_{5}-3,3062 x_{6}-2,2491 x_{7}}}{1+e^{2,4192+2,5779 x_{1}+1,7863 x_{2}-3,4902 x_{3}-2,4172 x_{4}+1,7679 x_{5}-3,3062 x_{6}-2,2491 x_{7}}}$ \\
\hline$x_{1}$ & (liabilities + other liabilities)/equity \\
\hline$x_{2}$ & (long-term loans + long-term bonds)/equity \\
\hline$x_{3}$ & operating profit / interest expense \\
\hline$x_{4}$ & operating profit / revenues \\
\hline$x_{5}$ & stock /(revenues/365) \\
\hline$x_{6}$ & financial assets / current assets \\
\hline$x_{7}$ & net profit /capital \\
\hline \multicolumn{2}{r}{} \\
\hline
\end{tabular}




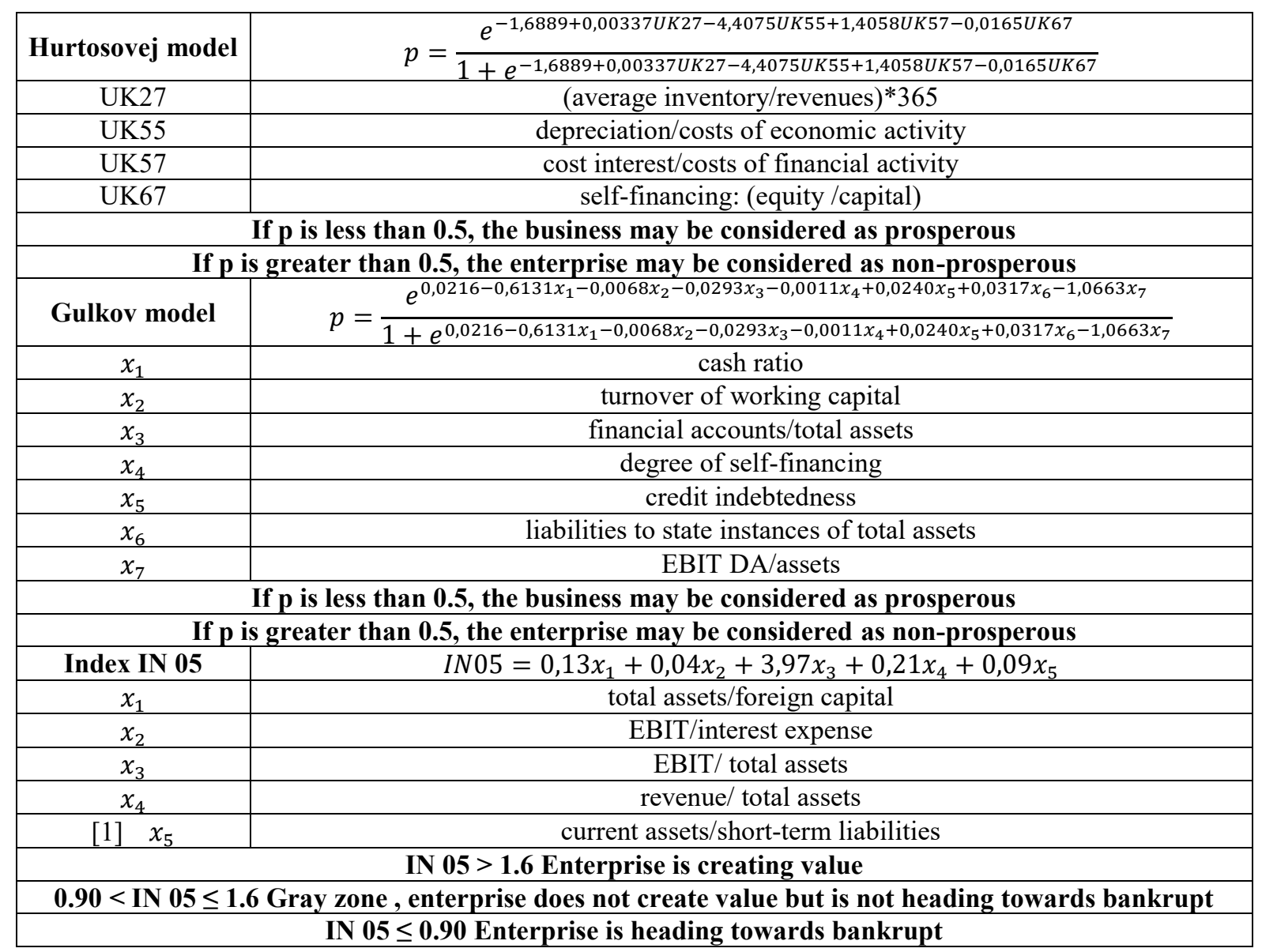

Other models have been developed in the Slovak Republic. In particular, the Chrastinova model, the Gurcik model and the Binkert model. These models are relatively known and used. We have decided not to calculate these models due to certain specificities associated with them. Chrastinova's and Gurcik's models are primarily oriented at agricultural enterprises and therefore we do not consider it correct to examine and compare their prediction ability in companies from other industries. The Binkert model, as the only one, takes the calculations of the three consecutive periods into account, but our database is comprised of 500 accounts that capture only 2 periods, namely 2016 and 2017, so we do not have the data necessary to calculate the model.

Finally, we compared the model's results with the inclusion of a business into a prosperous / nonprosperous category based on the established criteria. The results are briefly presented in the following chapter of the paper.

\section{Results}

In this contribution, we are working with a database consisting of 500 financial statements of Slovak enterprises that capture the years 2016 and 2017. The database is made up of companies that are filtered by ownership, and we used private ownership as a criterion for the type of ownership. Within the database we also work exclusively with companies whose legal form is a limited liability company. The resulting database was also cleared from the accounting units that reported negative assets in the balance sheet, as well as those that caused a division by zero within the selected financial indicators. Finally, we removed the units that were abolished during the reporting period. Brief characteristics of the database are found in Tables 2 and 3. 
Table 2. Regional representation of enterprises in the database (Source: author's compilation)

\begin{tabular}{|c|c|c|}
\hline Region & $\begin{array}{c}\text { Number of enterprises } \\
\text { (absolute value) }\end{array}$ & $\begin{array}{c}\text { Number of enterprises } \\
\text { in \% }\end{array}$ \\
\hline Bratislava & 96 & 19.20 \\
\hline Trnava & 53 & 10.60 \\
\hline Trenčín & 58 & 11.60 \\
\hline Nitra & 69 & 13.80 \\
\hline Žilina & 32 & 6.40 \\
\hline Banska Bystrica & 74 & 14.80 \\
\hline Presov & 55 & 11.00 \\
\hline Kosice & 63 & 12.60 \\
\hline Sum & 500 & 100.00 \\
\hline
\end{tabular}

Table 3 shows the five most represented regions in terms of number of enterprises. We do not further specify the other sectors and summarize the number of enterprises that are in them in the 'other'.

Table 3. Economic sector representation of enterprises in the database (Source: author's compilation)

\begin{tabular}{|c|c|c|}
\hline Economic sector & $\begin{array}{c}\text { Number of enterprises } \\
\text { (absolute value) }\end{array}$ & $\begin{array}{c}\text { Number of enterprises } \\
\text { in \%o }\end{array}$ \\
\hline $\begin{array}{c}\text { Wholesale and retail trade, repair of motor } \\
\text { vehicles and motorcycles }\end{array}$ & 125 & 25.00 \\
\hline Construction & 101 & 20.20 \\
\hline Industrial production & 83 & 16.60 \\
\hline Accommodation and catering services & 69 & 13.80 \\
\hline Information and communication & 55 & 11.00 \\
\hline Other & 67 & 13.40 \\
\hline Sum & 500 & 100.00 \\
\hline
\end{tabular}

On the basis of the criteria that we had described, in 2017, we classified the businesses into two groups: prosperous and non-prosperous. As a result of this classification, 383 prosperous and 117 nonprosperous enterprises were identified in total. Subsequently, the selected prediction models were calculated for all enterprises in 2017, and again, the enterprises were classified into two groups based on the results of the calculated models.

The results of the calculation of selected models can be found in Table 4 .

Table 4. An overview of the calculation of the financial health prediction models used (Source: author's compilation)

\begin{tabular}{|c|c|c|}
\hline Model & Prosperous enterprise & $\begin{array}{c}\text { Non-prosperous } \\
\text { enterprise }\end{array}$ \\
\hline Jakubik Teply model & 382 & 118 \\
\hline Hurtosova model & 342 & 158 \\
\hline Gulka model & 312 & 188 \\
\hline IN 05 & 395 & 105 \\
\hline
\end{tabular}

In the last part, as already mentioned, we focused on comparing the results and identifying the first and second type errors. This comparison was shown in the matrix of changes. The general matrix of the changes looks as follows (Table 5). 
Table 5. Matrix of changes (Source: author's compilation)

\begin{tabular}{|c|c|c|c|}
\hline \multicolumn{4}{|c|}{ Business classification based on predictive models } \\
\hline \multirow{3}{*}{$\begin{array}{c}\text { Business classification based } \\
\text { on selected criteria according } \\
\text { to The Commercial Code }\end{array}$} & $\begin{array}{c}\text { Non-prosperous } \\
\text { enterprise }\end{array}$ & $\begin{array}{c}\text { Non-prosperous } \\
\text { enterprise }\end{array}$ & $\begin{array}{c}\text { Prosperous } \\
\text { enterprise }\end{array}$ \\
\cline { 2 - 4 } & Prosperous enterprise & False Negatives & True Positives \\
\cline { 2 - 4 }
\end{tabular}

Where:

- True Positives - expresses a positive match, and hence, how many prosperous businesses were correctly classified as prosperous

- False Positives -- expresses how many non-prosperous businesses were classified as prosperous (error types I)

- True negative -- is a negative match, hence, how many bankruptcy businesses have been properly classified as bankrupt

- False Negatives -- expresses how many prosperous businesses were classified as nonprosperous (error types II)

The results of our comparisons are summarized in Table 6 .

Table 6. Comparison of results (Source: author's compilation)

\begin{tabular}{|c|c|c|c|}
\hline \multicolumn{4}{|c|}{ Business classification based on Jakubik Teply model } \\
\hline \multirow{2}{*}{$\begin{array}{c}\text { Business classification based on } \\
\text { selected criteria according to } \\
\text { The Commercial Code }\end{array}$} & $\begin{array}{c}\text { Non-prosperous } \\
\text { enterprise }\end{array}$ & Prosperous enterprise \\
\cline { 2 - 4 } & Non-prosperous enterprise & 286 & 48 \\
\cline { 2 - 4 } & Prosperous enterprise & 54 & 112 \\
\hline \multirow{2}{|c|}{ Business classification based on Hurtosova model } \\
\hline $\begin{array}{c}\text { Business classification based on } \\
\text { selected criteria according to } \\
\text { The Commercial Code }\end{array}$ & Non-prosperous enterprise & $\begin{array}{c}\text { Non-prosperous } \\
\text { enterprise }\end{array}$ & Prosperous enterprise \\
\cline { 2 - 4 } & Prosperous enterprise & 48 & 53 \\
\hline \multirow{3}{*}{$\begin{array}{c}\text { Business classification based on } \\
\text { selected criteria according to } \\
\text { The Commercial Code }\end{array}$} & Non-prosperous enterprise & $\begin{array}{c}\text { Non-prosperous } \\
\text { enterprise }\end{array}$ & Prosperous enterprise \\
\cline { 2 - 4 } & Prosperous enterprise & 48 & 68 \\
\hline & Business classification based on IN 05 & 149 \\
\hline \multirow{2}{*}{$\begin{array}{c}\text { Business classification based on } \\
\text { selected criteria according to } \\
\text { The Commercial Code }\end{array}$} & Non-prosperous enterprise & Non-prosperous & Prosperous enterprise \\
\cline { 2 - 4 } & Prosperous enterprise & 299 & 43 \\
\cline { 2 - 4 } & & 15 & 143 \\
\hline
\end{tabular}


Predictive ability of selected models is then determined as a percentage of correctly classified businesses.

Table 7. Predictive ability (Source: author's compilation)

\begin{tabular}{|l|c|c|c|c|}
\hline \multicolumn{1}{|c|}{ Model } & $\begin{array}{c}\text { Number of properly } \\
\text { classified enterprises }\end{array}$ & Type I error & Type II error & Predictive ability \\
\hline Jakubik Teply model & 398 & 48 & 54 & 79.60 \\
\hline Hurtosova model & 399 & 53 & 48 & 79.80 \\
\hline Gulka model & 384 & 68 & 48 & 76.80 \\
\hline IN 05 & 442 & 43 & 15 & 88.40 \\
\hline
\end{tabular}

In the case of the Jakubík Teplý model, 54 enterprises were included in our sample as non-prosperous, although according to the criteria chosen by us, they should not be in decline, but also not in risk of decline. 48 enterprises were among the prosperous although they can be at a risk of decline. In the case of the Hurtosova model, the situation was the opposite. Of the 67 enterprises wrongly classified, most enterprises (53) were ranked among the prosperous, although the ratio of their equity and liabilities was less than 0.06 . The remaining 48 businesses have been ranked as non-prosperous, although they are not non-prosperous according to our chosen criteria. The Gulka model, as well as the Hurtosova model, has classified among the prosperous enterprises many enterprises (68 enterprises) that should be classified as non-prosperous and 48 non-prosperous were classified as prosperous. The IN 05 index, which mistakenly classified only 57 enterprises, was the most accurate, with 15 of the companies that should have been in prosperous category and 43 in non-prosperous category but ranked opposite.

\section{Conclusions}

In our paper, we focused on predicting the financial health of Slovak enterprises through the selected Slovak and Czech models. We chose three Slovak and one Czech, which are most used. Based on the results, it can be stated that in almost $77 \%$ of the cases, these were enterprises with good financial health, which is a basic prerequisite for the future payment of the provided commercial loan in a timely manner. Nevertheless, we still recommend that businesses review the ability to reimburse the loan granted individually with each supplier, especially if it is a new potential business partner. Models of financial health predictions supplemented by basic computations in the framework of financial and economic analysis can provide a fast and relatively easy-to-read image of the financial situation of a business partner, which will ultimately support the right decision to grant or deny commercial credit. Bankruptcy models therefore deal with a possible default of the business, in other words, warn against the likely bankruptcy of a business. In bankruptcy models, their predictive ability is verified. We decided to verify their predictive ability through comparison results, which were obtained from calculation of selected models, to set criteria.

\section{Acknowledgements}

This research was financially supported by the Slovak Research and Development Agency Grant NO. APVV-14-0841: Comprehensive Prediction Model of the Financial Health of Slovak Companies.

\section{References}

Abiodun, S., Ullrich, F. \& Mueller, K. (2017). Financial issues challenging sustainability of rural pharmacies. American Journal of Medical Research, (4), 147-161.

Act no. 7/2005 Coll. on Bankruptcy and Restructuring

Altman, E. I. (2005). Corporate Financial Distress and Bankruptcy, New York, 156.

Cisko, S. \& Kliestik, T. (2013). Financny manazment podniku II. Zilina: EDIS Publishers, Zilina. 
Fanelli, V. \& Ryden, A. K. (2018). Pricing a swing contract in a gas sale company. Economics, Management, and Financial Markets, (3), 40-55.

Svabova, L. \& Kral, P. (2016). Selection of Predictors in Bankruptcy Prediction Models for Slovak Companies. In 10th International days of statistics and economics. Conference proceedings, 1759-1768.

Gulka, M. (2016). Model Predikcie Úpadku Obchodných Spoločností Podnikajúcich v Podmienkach SR. Biatec, (2), 5-9.

Gurcik, L. (2002). G-index - Metóda Predikcie Finančného Stavu Pol’nohospodárskych Podnikov. Agricultural Economics, (48), 373-378.

Chrastinova, Z. (1998). Metódy hodnotenia ekonomickej bonity a predikcie finančnej situácie pol'nohospodárskych podnikov. Bratislava: Výskumný ústav ekonomiky pol'nohospodárstva a potravinárstva.

Jones, F. L. (1987). Current techniques in bankruptcy prediction. Journal of Accounting Literature, (6), 131-164.

Mousavi, M, M., Ouenniche, J. \& Xu, B. (2015). Performance Evaluation of Bankruptcy Prediction Models: An Orientation-free Super-efficiency DEA-based Framework. International Review Of Financial Analysis, (42), 6475 .

Neumaierova, I. \& Neumaier, I. (2005). Index IN05. In Evropske finančni systemy: Sbornik přispěvků z mezinarodni vědecke konference. 143 - 147.

Rowland, Z., Dvorakova, L. \& Rousek, P. (2016). Determination of bankruptcy model of transport companies in the Czech Republic by using multiple discriminant analysis. Ekonomicko-manazerske spektrum, (10), 32-46.

Virag, M. \& Kristof, T. (2005). Neural Networks in Bankruptcy Prediction: A Comparative Study on the Basis of the First Hungarian Bankruptcy Model, Acta Oeconomica, (55), 403-426.

Weissova, I. \& Durica, M. (2016). The possibility of using prediction models for monitoring the financial health of Slovak companies. In Managing and modelling of financial risks : 8th international scientific conference, 1062-1070.

Weissova, I. \& Gregova, E. (2016). The Role of Selected Variables in the Issue of Credit Risk of Company. In ISSGBM International Conference on Information and Business Management (ISSGBM-IB 2016), Lecture Notes in Management Science, (61), 60-66.

Zavgren, C.V. (1985). Assessing the vulnerability to failure of American industrial firms: a logistic analysis. Journal of Business Finance \& Accounting, (12), 19-45. 